\title{
Reducing reservoir impacts and improving outcomes for dam- forced resettlement: experiences in central Vietnam
}

\author{
$\operatorname{AUTHOR}(\mathrm{S})$ :
}

Singer, Jane; Watanabe, Tsugihiro

\section{CITATION:}

Singer, Jane ... [et al]. Reducing reservoir impacts and improving outcomes for dam-forced resettlement: experiences in central Vietnam. Lakes \& Reservoirs: Research \&

Management 2014, 19(3): 225-235

\section{ISSUE DATE:}

2014-09-17

URL:

http://hdl.handle.net/2433/199877

\section{RIGHT:}

This is the peer reviewed version of the following article: Singer, J. and Watanabe, T. (2014), Reducing reservoir impacts and improving outcomes for dam-forced resettlement: experiences in central Vietnam. Lakes \& Reservoirs: Research \& Management, 19:225-235, which has been published in final form at http://dx.doi.org/10.1111//re.12072. This article may be used for non-commercial purposes in accordance with Wiley Terms and Conditions for Self-Archiving.; The fulltext file will be made open to the public on 17 SEP 2015 in accordance with publisher's 'Terms and Conditions for SelfArchiving': この論文は出版社版でありません。引用の際には出版社版をご確認ご利用ください。; This is not the published version. Please cite only the published version. 
Reducing reservoir impacts and improving outcomes for dam-forced resettlement: Experiences in central Vietnam

By Jane Singer and Tsugihiro Watanabe

Graduate School of Global Environmental Studies, Kyoto University

Address:

Graduate School of Global Environmental Studies

Kyoto University

Yoshida-Honmachi, Sakyo-ku

Kyoto, Japan 606-8501

Email: singer.jane.6e@kyoto-u.ac.jp

Tel: +81-75-753-5933

Fax: $+81-75-821-9160$

Running title: Reducing reservoir impacts

Acknowledgements

This research was supported by a grant in aid from the Japanese Society for the Promotion of Science, No. 23651036. 


\section{Reducing reservoir impacts and improving outcomes for dam-forced resettlement: Experiences in central Vietnam}

This paper addresses the growing problem of human displacement due to hydropower dam construction within the context of integrated lake basin management (ILBM) of dam reservoirs. Dam-forced displacement and resettlement can pose severe challenges to the environmental, economic and social sustainability of a reservoir basin. As suggested by a case study in Quang Nam province, central Vietnam, many resettled communities experience impoverishment due to the lack of adequate replacement land, declines in supplemental food sources and reduced access to natural resources. In response, resettled residents may destroy lake catchment forests for farmland conversion or engage in illegal logging; increase agrichemical inputs on reduced land, thereby polluting runoff and groundwater; and place increased pressure on fish stocks and wildlife. The author provides examples from central Vietnam to illustrate the need for applying approaches that makes affected people beneficiaries of dam projects and by including civil society organisations in resettlement planning. The hydropower authority can fund benefit sharing mechanisms, including village-level electrification and payment for environmental services (PES) schemes, in which resettled populations are paid for forest maintenance and protection in order to prevent erosion and deforestation, and reservoir access can be provided for fishing, aquaculture and agriculture. Civil society organizations can advocate for residents' interests and for reallocation of protected forest land for community forestry. These approaches can be supported by an inclusive reservoir management board working to achieve environmental sustainability, economic growth and social equity.

Key words: Benefit-sharing mechanisms, dam-forced displacement, reservoir management, Vietnam

\section{Introduction}

Reliance on hydropower generation to meet growing demand for electricity in the developing world has fuelled a recent boom in construction of large hydropower dams. The International Commission on Large Dams (ICOLD 2013) estimates that there are 8,689 single- and multi-purpose large dams (height of $15 \mathrm{~m}+$ ) worldwide producing 2.3 trillion of kilowatt hours of hydropower a year. China and India claim the second and third largest number of large dams, respectively, with more than 5,000 dams each (ICOLD 2013).

Much has been written on the adverse environmental impacts of dam construction on river basins, including reduced sediment flow, loss of fisheries, eroded 
riverbeds and altered downstream flows (see Fearnside 2001, Bunn \& Arthington 2002, Kuenzer et al. 2012). Artificial reservoirs created by dam impoundment have also raised environmental concerns regarding the loss of aquatic species, sedimentation, salinity, emission of greenhouse gases and adverse impacts on impounded terrestrial ecosystems (World Commission on Dams 2000, MOIT 2009). However, environmental impacts on lake and river basins from anthropogenic causes cannot be effectively remediated without taking into account the needs and contingencies of those living in the reservoir basin area and in downriver communities affected by water quality and flow regulation. This includes an accurate assessment of indirect environmental risks from the resettlement of populations displaced by dam construction (Tan \& Yao 2006), as well as an understanding of the socioeconomic implications of dam-forced displacement and resettlement.

Dam-forced resettlement can profoundly affect the physical and socioeconomic environment of a river basin, as shown in Figure 1. Development of roads, homes, agricultural plots and other new infrastructure for resettlers may fragment or degrade ecosystems, while spurring additional in-migration from outside the area. Improved road access to remote areas often leads to increases in illegal logging and resource use. Conflicts with host communities may result from ethnic or religious differences or competition for employment (Koenig 2006). Competition with other residents may also arise for agricultural land and common pool natural resources, causing resettlers to cut or burn nearby forest land for agricultural conversion and leading to depletion of local fisheries and wildlife (MOIT 2009). The resulting erosion and deforestation may adversely affect water flow and quality for drinking, irrigation and hydropower generation. Tan and Yao (2006) identified six major types of environmental consequences of dam-induced resettlement: increased pressure on the carrying capacity of surrounding land, loss of vegetation and soil erosion from land reclamation, pollution from industrial and commercial activity, environmental degradation due to urban relocation, landslides near reservoirs, and social impacts of displacement.

<FIGURE 1 River basin impacts of dam-induced resettlement>

This paper will explain issues arising from dam-induced displacement and resettlement and employ a case study of resettled ethnic minority residents in an upland region of central Vietnam to examine some of the environmental, economic and social implications for reservoir and river basins. I will then discuss the steps that can be taken by varied stakeholders, including the hydropower authority, domestic civil society organisations and local governments, to improve resettlement outcomes based on an 
integrated lake basin management approach.

\section{The growing problem of dam-induced displacement and resettlement}

Sociologist Michael Cernea (2007) estimates that worldwide 10-15 million people are displaced each year by development, including hydropower dam construction. Displaced populations risk the loss of homes, land and livelihoods; increased food insecurity and morbidity; economic, social and psychological marginalization; and lost access to common resources and fragmented community ties (Cernea 2000). Many of those displaced, especially in developing countries, are ethnic minority agriculturalists who rely heavily on forest, rivers and other natural resources for livelihoods.

In a global survey of 50 hydropower dam projects, Scudder (2005) found that the majority of those resettled due to dam construction suffered impoverishment. While most displaced populations receive some monetary compensation for lost homes and property, compensation is often inadequate or delayed, and as cash is rarely spent on productive assets, it may soon be exhausted. Displaced farmers may receive replacement land, but it is often less fertile than the original riverside plots, far from new settlements, or land that has been appropriated from original residents without adequate compensation, causing conflict between host and resettled communities. Even when initial monetary compensation is adequate, funding and assistance linked to dam-forced resettlement projects generally cease after the dam construction project cycle is complete, and livelihood prospects may deteriorate thereafter (Nayak 2000).

According to Scudder (2005), the loss of economic power after displacement, accompanied by social and psychological marginalization, is highly associated with poor resettlement outcomes, as is the loss of community ties and social articulation. In most of these cases, he noted, resettlers are unable to move as a unit. Disruption of one's previous spatial or temporal order has been found to cause long-lasting anxiety, particularly for elderly residents (Downing \& Garcia-Downing 2009). Johnston (2012, p. 305) has written that "hydrodevelopment - in the enclosure and destruction of the world's riverine ecosystems commons - may be one of the most significant factors driving global poverty rates.”

\section{Dam construction and displacement in Vietnam}

In Vietnam, rapid economic growth has been accompanied by electricity demand that is rising by $15-17 \%$ per annum (Dao 2010). The nation currently relies on hydropower for $37 \%$ of electricity generation and the government projects that hydropower capacity will reach up to 80 billion KwH by 2020 (MOIT 2009). Vietnam's ten major river basins are blanketed with dams now operating or under construction, with 70 large dams 
with a capacity of 30MW or more of electricity in operation as of 2009 (Dao 2010).

The human and environmental costs of large hydropower dam projects have become the focus of growing media attention. In recent years Vietnam has experienced widespread declines in river water quality that have been linked to dam construction; low flow during the dry season, causing rivers to run dry (as with the Dak Mi 4 dam in Quang Nam province, 2013) and urban areas to experience electricity brownouts; and degraded fisheries, forests and biodiversity. In 2010, due to prolonged drought, reservoir levels and hydropower generation dropped sharply from levels of previous years, leading to concern over its long-term reliability (CSRD, 2013). There have been several widely reported dam-related scandals and accidents, including cracked walls and water leakage due to shoddy construction, sudden storm-water releases from the Yali Falls dam in September 2005 that inundated downstream areas and communities (Hirsch 2006), and destructive tremors caused by water pressure in a reservoir situated over a previously unidentified fault lines at the Song Tranh 2 dam (Viet Nam News 2013). In addition, as was reported in a government-initiated strategic environmental assessment report on hydropower development in Vietnam, "One key problem with existing practices is that each hydropower scheme is managed in isolation without taking into account the cumulative impacts of multiple schemes within river basins” (MOIT 2009), referring to recurrent problems such as unpredictable fluctuations in river flow. In May 2013 the government cancelled previously approved plans to construct 338 hydropower dams due to environmental risks, and scrubbed an additional 67 hydropower projects by August 2013 (Nguyen 2013).

Dam construction has uprooted tens of thousands of upland residents in Vietnam, with the Son La dam, the largest dam in Southeast Asia, displacing a total of 91,000 residents across three northern provinces (Bui \& Schreinemachers 2011). Although national legislation has been revised several times in recent years to provide for improved terms of compensation and post-resettlement support by those responsible for resettlement, mainly local government and the hydropower project authority, poor outcomes continue to be recorded, mainly due to the provision of unproductive replacement land, constrained access to forests and fisheries, reduced or delayed financial compensation, exclusion from decision-making on resettlement issues such as relocation sites and housing, and inadequate mechanisms for settling grievances (see Beckman 2011; Bui \& Schreinemachers 2011; Bui, Schreinemachers \& Berger 2012, Dao 2010 and Ty, Van Westen, \& Zoomers 2013). The greatest single shared issue, however, is the lack of productive land (MOIT 2009).

\section{Case study of dam-induced displacement in central Vietnam}


The example of a hydropower dam in central Vietnam illustrates some of the difficulties attending dam-forced resettlement. Members of three ethnic minority villages were resettled due to construction of the A Vuong 210MW hydropower dam in Ma Cooih commune, Dong Giang district, Quang Nam Province in central Vietnam (see Figure 2). The dam was completed in 2006, and residents living beside the A Vuong river, a tributary of the Vu Gia river, were resettled in the same year to three different locations. The author conducted research in two adjacent villages, Aden and Tro Gung, located approximately 20 kilometres from the dam reservoir, including 58 semi-structured household interviews, six focus group discussions and surveys of all 120 households. The combined permanent population of the villages is 569, and $95 \%$ of the population are ethnic Co-tu, one of the 53 indigenous ethnic minorities in Vietnam. Each resettled household was allocated a residential plot measuring 400 square meters (Asian Development Bank 2007), 750 square meters of land for upland cultivation and 500 square meters for wetland rice cultivation. As no data was available for farm harvests and other sources of livelihood prior to resettlement the authors relied on farmers' subjective assessments of changes in living conditions and livelihoods.

$<$ FIGURE 2 Field site $>$

All the respondents to semi-structured interviews agreed that physical infrastructure was greatly improved after resettlement, particularly in terms of provision of electricity, roads, and a primary school. In focus group discussions residents identified as their greatest current problems, in order of response frequency, as land quality and quantity, lack of water for irrigation and household use, difficulty in accessing natural resources and poor housing stock. They reported that due to poor soil quality in their new plots it took an average of two years to harvest cassava, compared to one year before the move. Due to poor irrigation paddy rice harvests are only sufficient to feed a four-member family an average of three months per year.

Local forest cover has declined in the area since resettlement due to infrastructure development, illegal logging and conversion for agricultural use, typically by clearing and burning of foliage by villagers who were unable to produce enough crops to secure food security with the land they had received after the move. According to a middle-aged woman in a January 2012 focus group: “The forest was better before [resettlement] so we could cut down large trees for building houses. There was lots of timber and wildlife as well, so we didn't worry when we moved from one site to another. Illegal logging has destroyed much of the forest so we can't rely on the forest anymore.” A survey of the A Vuong dam project area totalling 81,000 hectares, including 
land downstream, examined forest loss over a ten-year period. As shown in Table 1, they found that total forest cover, including both natural and plantation forest, declined from 64.63 percent in 2003, at the start of the dam project to $57.16 \%$ in 2013 . Natural forest declined from 60.68 percent to 53.5 percent over the same period (Quang Nam, 2013). In 2008, after resettlement, a large decline in vacant land was recorded $(23,604$ to 14,145 hectares), reflecting the unsanctioned conversion of forest land for agriculture by the villagers.

\section{(TABLE 1)}

In focus groups and household interviews residents reported reduced access to fisheries and forest wildlife, two important food sources before resettlement (MONRE, 2008). An environmental impact assessment conducted before the dam was constructed (Electricity of Vietnam, 2004) found 21 species of fish in the A Vuong river, including two endangered species recorded in the Red Book of Vietnam, Anguilla marmorata, a type of eel, and a snake-head species, Channa striata. According to semiannual environmental monitoring reports commissioned by the provincial government, the biodiversity and quantity of fish in the A Vuong reservoir is low, with only 20 total aquatic species recorded and one type of zoobenthos averaging 20 per square meter. Although most households reportedly harvested river fish before the move, only three of 120 households in two villages surveyed in 2012 reported that they regularly caught fish for family consumption; the others either purchased fish or no longer ate it, in part because the resettled villages were far from the A Vuong river. Some villagers reported that they travelled far downriver to catch fish only for weddings or special events. The district government has denied the villagers access to the dam reservoir for fishing or aquaculture, citing concerns about water pollution. The percentage of households who regularly engaged in hunting also declined, from $16 \%$ before resettlement to $7.6 \%$ in 2012. One farmer noted a lack of forest wildlife available for trapping (March 2012), while others stated that their catch was mainly rodents and other small animals. Hunting has also been complicated by strict government laws forbidding catches of large animals, especially in light of severe recent declines in terrestrial biodiversity (SEA, 2008).

Institutional factors and poor local implementation also had adverse implications for the resettled residents. For dam-displaced populations Vietnam's weak local governance, the lack of institutional mechanisms for participation in resettlement decision-making, and negative attitudes about the competence of ethnic minorities to make appropriate decisions (Scott, Miller \& Lloyd 2006) have often limited their ability to play active roles in deciding resettlement locations, livelihood support initiatives or 
housing styles. Because homes constructed for residents of in the case study villages were cramped, poorly built and poorly suited to their lifestyles, they were compelled to expend limited land and resources for repairing broken staircases, renovating homes and constructing supplementary housing. Some residents constructed up to four new structures, including traditional thatched homes for elderly family members, instead of using adjacent land for productive home-gardens. Another group of residents displaced by the A Vuong dam was resettled in 2006 on a narrow riverbank beside an eroded slope downriver of the dam, although the site was not their initial choice. The site subsequently experienced severe landslides each year during the rainy season, and several homes and buildings were washed into the river, necessitating re-resettlement to a safer site far from the A Vuong river and causing considerable conflict between local government and residents who demanded greater compensation for the move.

\section{From displacees to beneficiaries: Paying for forest ecosystem services}

Since dams are often built in relatively impoverished, less populated upland regions by outside investors, both electricity supplies and revenues commonly accrue to distant urban and industrial centres, leaving few benefits for local residents. According to the World Commission on Dams, "People adversely affected by a dam project should be the first to benefit from the project. Appropriate mechanisms should be introduced to ensure equitable distribution of development opportunities generated by the dam" (2000 p. 243). These benefits and opportunities may include compensation, infrastructure, and employment in dam construction or maintenance positions, but these may be one-time or short-term in nature. In recent years a number of other benefit-sharing mechanisms have been implemented for dam-displaced residents, including community-wide electrification, irrigation and electricity, often at preferential rates; non-monetary benefits, such as allowing resettled residents to access reservoir fisheries and practice aquaculture or cultivate drawdown areas of the reservoir; and revenue sharing, including endowing community development funds managed with participation by residents (Haas 2009). In one revenue sharing scheme in Japan, for example, farmers were paid rent for the term of hydropower generation for land that had been inundated by dam construction (Nakayama \& Furuyashiki 2009). In an Asian Development Bank-funded pilot project initiated in 2006 in the abovementioned A Vuong research area in Vietnam resettled residents were included in a series of workshops that sought to identify their preferences in using hydropower tax revenues. They selected livestock and agricultural training, rural credit schemes, aquaculture and reservoir fisheries and subsidized electric provision for poor households (Haas, 2009). However, as Mokorosi and van der Zaag 2007) noted in an analysis of two dam projects in southern Africa, although benefit 
sharing is often upheld as an ideal, in reality affected people tend to enjoy mainly indirect benefits like community services or livelihood assistance and the most vulnerable, such as farm workers, benefit less than owners of farm land, who receive cash or land-for-land compensation. They suggest that national benefit-sharing policies be adopted, the right to participate be enshrined in legislation and an inclusive implementation strategy be enacted.

The hydropower authority, as the major beneficiary of hydropower generation revenues and the environmental regulating services of healthy watershed forests, can be said to bear an ethical responsibility for sharing its revenues with the impacted communities that have suffered for "the greater good" (De Wet 2006). Based on the "user pays" principle, the Vietnamese government is now creating a legal framework for nationwide implementation of a benefit-sharing mechanism called payment for environmental services (PES) that taxes providers of hydropower, irrigation and ecotourism. A PES scheme has been defined as "a voluntary transaction in which a well-defined environmental service (ES), or a form of land use likely to secure that service, is bought by at least one ES buyer from a minimum of one ES provider if and only if the provider continues to supply that service” (Wunder 2005). PES schemes not only provide ES providers with steady streams of income, but they provide clear incentives for them to conserve common-pool resources such as forests and rivers. Previous schemes in Latin America and elsewhere included public sector schemes, private market schemes and direct private deals between seller and buyer (Wunder 2008). In this case, however the PES scheme is government-mandated and participation is involuntary.

In Vietnam, PES is regarded as a key strategy for alleviating rural poverty and conserving the nation's dwindling forests and biodiversity. Recently enacted PES legislation (99/2010/ND-CP Law on Payment for Environmental Services) stipulates that three categories of ecosystem service beneficiaries, electricity utilities, public water utilities and ecotourism providers, pay for forest environmental services such as water regulation and soil conservation (for water and electric utilities) and for protection of landscape quality (for tourism companies). The rate is fixed at 20 VND (0.0009 USD) per kilowatt hour for hydropower producers and 40 VND per cubic meters for water suppliers (Government of Vietnam 2010). Ecotourism operators need to contribute between $0.5-2 \%$ of annual tourism revenues (Chiramba et al. 2011). Tax revenues are paid to the provincial government, then a portion is disbursed to a Forest Protection and Development Fund at the district level and then to local households. Residents are expected to conserve the forest area in the river watershed, by planting trees, monitoring changes in forest cover, patrolling to prevent illegal logging and branch-trimming and 
forest maintenance. These efforts are expected to help reduce erosion and sediments in the reservoir, thus contributing to improved live storage capacity. The program has drawn considerable attention as one of the first such nationwide PES initiatives in Southeast Asia.

In a pilot scheme implemented from 2009 in Dong Giang district of Quang Nam province, central Vietnam, resettled farmers and those in two neighbouring villages were taught about forest maintenance and ecosystem services by an international NGO, Winrock International. Groups of residents jointly patrolled the forest and built and manned a road block to catch unauthorised loggers. Village officials claimed that illegal logging declined by $50 \%$ during the PFES program, although official monitoring had not yet been conducted. However, transaction costs were high, according to an officer with the district forest protection management unit (personal conversation, 2012), partly due to implementation of an initial baseline study to determine initial forest cover, quality and composition and periodic forest monitoring. Because tax revenues alone can't fully fund the forest protection project, the Asian Development Bank provided additional funding for forest monitoring and training courses.

Along with passage of the new legislation PES schemes are being scaled up for implementation nationwide, but concern remains for their environmental and economic sustainability. Although community and household tree plantations increase forest cover, widespread preferences for fast-growing trees like acacia contribute little to forest biodiversity. The lack of strict forest monitoring or differential payments for forest conservation may reduce participant motivation for monitoring remote forest areas. In addition, corporate investors in small and medium-sized dams in Vietnam have recently protested compulsory environmental taxes, citing weak revenues. In conclusion this program, if implemented nationwide, promises a small but steady source of income for residents but not a solution to the problems raised by displacement.

\section{Civil society organisations: Advocating and negotiating for residents}

In many countries civil society organizations have played major roles in improving resettlement outcomes. The groups include international and domestic non-governmental organisations (NGOs), community-based groups, faith-based groups, labour unions, and research centres. International development NGOs often provide assistance in health, nutrition and agricultural support for resettlement communities as part of larger national programs. Domestic NGOs can help improve post-resettlement living conditions and represent residents with government and project management in many developing countries. In the Narmada river basin of central India, for example, 
NGOs have supported livelihood training and helped to improve infrastructure in resettlement villages, despite having actively protested construction of the dams that had caused the initial displacement (Pandya 2013). In India NGO expertise is commonly requested and their involvement in resettlement is funded as a way of supplementing limited local government capacities. In Cambodia, where CSO-government relations are often contentious, human rights and development NGO representatives support civil resistance and advocate for displaced residents to government and international bodies like the United Nations (Mgbako et al. 2010). In Indonesia, CSO representatives have worked with the government to enable resettled farmers to access reservoir capture fisheries, engage in aquaculture and cultivate reservoir drawdown areas (Munro, Iskander \& Costa-Pierce 1990).

Although large international NGOs such as World Vision and Oxfam have occasionally provided material or agricultural extension support, inclusion of domestic CSOs in dam-forced resettlement projects is a recent phenomenon in Vietnam. The Communist Party leadership of Vietnam long prohibited activity by autonomous groups like domestic NGOs, leading to what has been called "state-led civil society" (Lux \& Straussman 2004). Since the Doi Moi economic liberalization reforms of the 1980s, however, there has been growing tolerance for non-governmental and community groups, manifested in a stronger legal framework for recognizing CSOs, expanded media coverage and an explosion in the number of self-proclaimed non-government organisations (Kirkvliet, 2003). Passage of a national law in 2003 that allowed community-based groups to join commune-level development has helped to ease participation by local NGOs in development projects (Thayer 2009).

NGOs have recently played strengthened advocacy and livelihood support roles in several Vietnamese resettlement villages. In $\mathrm{Hu}$ Ta district in Thua Thien Hue province, for example, a local NGO surveyed protected forest land near the villages to identify 169.2 hectares of unutilized land. They negotiated with the district to reallocate the land to resettled households in eight villages for plantation of indigenous bamboo and other trees. All land is owned by the state in Vietnam, with residents, communities or corporations accorded land use rights for a specified number of years (Kolinjivadai \& Sunderland 2012). Recent Vietnamese legislation provides for the reallocation of unused state forest enterprise land to poor and landless rural households in order to decrease deforestation and increase household income, but so far local officials have been reluctant to allow devolution of land title to the rural poor (McElwee 2009). In Hu Ta district, though, due to NGO intervention, residents were provided land and land use certificates and were trained in workshops on land law and land use rights. The certificates were used as collateral for low-interest bank loans for saplings, fertilizer and 
preparation of land for cultivation, as well as for household expenditures. Local officials were also trained in land use planning, land allocation processes and licensing of forest land use rights.

Another category of CSOs that have been active in resettlement support are the rural development centres that can be found at many Vietnamese universities, particularly universities of agriculture and forestry, which work with district or provincial governments to implement livelihood, managerial and agricultural initiatives. The first centres began activities after Decision 3059/QD-TCCB was promulgated in 1992 by the Ministry of Education and Training, allowing Vietnamese universities to procure funding from foreign ODA agencies or international NGOs. These centres, though typically administered and staffed by national universities, often have outside project funding, and may characterise themselves as non-governmental organisations, reflecting the blurred boundaries of state and civil society in Vietnam.

Rural development centres can draw on the expertise of university faculty and researchers in agriculture, livestock husbandry, forestry, sanitation, environmental conservation and other fields by piloting new technologies and approaches in resettlement communities. Rural residents and officials gain from inclusion in development initiatives and training courses. Local governments can harness centre expertise to supplement their own agricultural extension services.

Because Vietnamese universities often dispatch faculty to remote rural areas to teach extension courses to adult students (often local officials), development centre staff can call on university alumni at every level of local government, easing the local approval process for development initiatives and allowing staff to advocate on a personal level for the needs of APs. In addition, universities can recruit their ethnic minority students to help translate local languages, and university faculty are often familiar with local climatic and soil conditions and locally appropriate crops and livestock (Hoang Manh Quan, personal communication, September 20, 2013).

The Centre for Rural Development in Central Vietnam (CRD) of Hue University of Agriculture and Forestry is one of the best-known university CSOs in central Vietnam. In a recent project funded by a Danish NGO, CRD researchers worked with commune officials, the Thien Thua Hue province department of natural resources and the local forest protection management unit to identify degraded forest land beside the Binh Dien dam reservoir for reallocation to six groups of resettled farmers for community forestry. The farmers planted indigenous bamboo species on 5-hectare plots, thereby contributing to forest conservation and gaining a new source of income (CRD 2013). 


\section{Discussion}

To achieve the goals of environmental sustainability, economic growth and social equity embodied in integrated management of a lake basin where dam-displaced residents have been resettled, some efforts should be made to share the benefits of hydropower dam construction in an equitable way. This may involve a formal mechanism, such as the PES scheme mentioned earlier, or bestowing permission for using the reservoir for income-earning activities such as fishing, aquaculture or agriculture. It may also involve using a heretofore single-purpose hydropower dam reservoir for irrigation or flood control for downstream residents, and including residents' representatives, NGOs or local community organizations in lake basin management. However, the latter has proven problematic in Vietnam. Management of a hydropower dam reservoir in Vietnam is generally the responsibility of the hydropower authority, with priority given to financial considerations (IWMI, 2011). By law the provincial government plays an advisory role, particularly through its local forest management protection unit, part of the province's Department of Agriculture and Rural Development, and national agencies such as the Ministry of Natural Resources (MONRE) and Ministry of Industry and Trade (MOIT) must approve operational decisions. As Thanh (2013) has noted, overlaps in ministerial oversight and responsibility for water resources in Vietnam make integrated approaches in managing river or lake basins very difficult. For example, although MONRE is tasked with managing water resources overall, water for industrial activities is overseen by MOIT, water for domestic use by the Ministry of Construction, and water for agriculture by the Ministry of Agriculture and Rural Development.

Another common problem in Vietnam is the gap between policy and practice. For example, although when conceiving a national power development plan the government and EVN, the parastatal electric utility, formally endorsed use of hydropower dam reservoirs for multiple purposes, including recreation, fishing, tourism, drought alleviation and local irrigation (MONRE, 2008), most reservoirs are solely used for power production. In addition, although the hydropower authority has been assigned overall reservoir responsibility the district government may allow local residents to access the reservoir without consulting with the hydropower authority (IWMI, 2011). The authority's actual enforcement area may be limited to the hydropower facility and immediate surroundings.

Dam and other infrastructure projects in Vietnam are governed by laws on land acquisition and resettlement offering incrementally improved and detailed terms of compensation but there remains a lack of transparency of resettlement processes and residents are unable to provide prior, free and informed consent to resettlement decisions (Singer and Hai, 2013-14). As with many infrastructure projects in the 
developing world, residents suffer from asymmetric access to project information, weak financial clout and inadequate representation in implementation bodies, although they may passively participate in pre-resettlement meetings with local government and investors.

Improvement of outcomes for resettled residents clearly depends on a range of factors, from fair compensation and quality housing to provision of suitable land and livelihood support. However, approaches linked to reservoir management could help to address some of the problems identified here. In particular, the following steps could be taken in a Vietnamese ILBM approach that includes six pillars of governance:

1. Institutions: Reduce overlap in authority and poor cooperation between institutions involved in reservoir access and management by establishing a single management board with clearly denoted responsibilities and command.

2. Policies: Formulate or support local benefit-sharing initiatives such as reservoir access, electrification, agricultural and livelihood support, and payments for environmental services.

3. Participation: Include village heads, representatives of locally active NGOs and mass organizations like the Farmers' Union, district and commune officials as well as the hydropower authority in a broad-based management board. This would improve articulation of residents' concerns and would also enhance local representatives' understanding of the importance of ecological conservation of the watershed.

4. Technology: Assistance in improving irrigation, water supplies and poor sanitation for resettled residents could be provided by organizations or experts linked to the reservoir management board.

5. Information: Estimate potential water demand and water resource potential of the lake basin to determine available resources for sharing with residents. Monitor water quality, fisheries and biodiversity of the watershed to assess the impact of dam operations and local activities and establish a database for broader information-sharing (Thanh, 2013).

6. Financing: Funds from hydropower generation can be shared with local residents in a PES scheme and used for other benefit-sharing approaches. Allocation of funds should be based on the needs of local residents and ecosystem health as well as the interests of hydropower investors in a long-term approach.

\section{Conclusion}

The displacement and resettlement of residents for construction of a dam poses a number of challenges to achieving the ideals of integrated water resources management, 
namely "the coordinated development and management of water, land and related resources in order to maximize the resultant economic and social welfare in an equitable manner without compromising the sustainability of vital ecosystems" (Rahaman and Varis, 2005, p. 15). Not only have most displaced residents been unable to restore or improve their living standards they have often contributed to environmental degradation by conversion of forest land for agricultural production, polluting groundwater or engaging in illegal logging.

As case studies in central Vietnam have shown, local government and the dam project authority alone have been unable to achieve successful resettlement outcomes to date, suggesting that participation by a broad array of actors could help address the common resettlement issues of insufficient productive land and poor local governance and provide support for resettled residents long after formal assistance linked to a dam project term has ceased. Hydropower authorities can participate in implementing benefit-sharing mechanisms, such as electrification of affected communities, providing access to reservoir fisheries, and PES schemes, like the approach that is currently being implemented in Vietnam, to share benefits of hydropower generation and irrigation supplies with resettled residents while supporting protection of ecological services, improving conservation of forests and extending the productive life of the reservoir. Civil society organizations can advocate for residents and promote land reallocation or access to reservoir fisheries and cultivation of drawdown areas through negotiations with local government officials. Reservoir management committees can include representatives from district, commune and village government, NGOs, and mass organisations like the Farmers' Union from the planning stage. An approach that incorporates multiple stakeholders in planning hydropower dams and the resulting displacement and resettlement promises improved long-term outcomes for reservoir health and resident well-being alike.

\section{Acknowledgment}

This work was supported by funding by the Japan Society for the Promotion of Science \# 23651036.

\section{References}

Asian Development Bank (2007) Benefit Sharing Mechanisms for People Adversely Affected by Power Generation Projects in Viet Nam (2007). Final Report. Appendix L: Rapid Appraisal Report on the A' Vuong Project. Available from URL: http://www.adb.org/Documents/Produced-Under-TA/39379/39379-VIE-DPTA.pdf.

Accessed 28 July, 2011. 
Beckman, M. (2011) Converging and conflicting interests in adaptation to environmental change in central Vietnam. Clim. and Dev., 3(1), 32-41.

Bui, T.M.H. \& Schreinemachers, P. (2011) Resettling farm households in northwestern Vietnam: Livelihood change and adaptation. Int. J. of Water Res. Dev. 27(4), 769-785.

Bui, T.M.H., Schreinemachers \& Berger, T. (2013) Hydropower development in Vietnam: Involuntary resettlement and factors enabling rehabilitation. Land Use Policy, 31, 536-544.

Bunn, S.E. \& Arthington, A.H. (2002) Basic principles and ecological consequences of altered flow regimes for aquatic biodiversity. Envir. Mgmt., 30(4), 492-507.

Center for Rural Development in Central Vietnam (2013) Community Development. Available from URL: http://www.crdhue.com.vn/english/index.php. Accessed 4 September 2013.

Centre for Social Research and Development (CSRD) (2013) Research report: Comparison of the approval process detailed in government regulations with the actual approval and planning process for hydro-power plant development in the Vu Gia-Thu Bon river basin in Quang Nam province and Long Dai river basin in Quang Binh province.

Cernea, M.M. (2000) Risks, safeguards, and reconstruction: A model for population displacement and resettlement. In: Risks and Reconstruction: Experience of Resettlers and Refugees (eds M.M. Cernea \& C. McDowell) pp. 11-55. World Bank, Washington, D.C.

Cernea, M.M. (2007) IRR: An operational risks reduction model for population resettlement. Hydro Nepal: J. of Water, Energy and Envir., 1(1), 35-39.

Chiramba, T., Mogoi, S., Martinez, I. \& Jones, T. (2011) Payment for forest ecosystem services (PFES): Pilot implementation in Lam Dong province, Vietnam. Paper presented at the UN-Water International Conference: Water in the Green Economy in Practice: Towards Rio + 20, Zaragoza, Spain, October 2011.

Dao, N. (2010) Dam development in Vietnam: The evolution of dam-induced resettlement policy. Water Alternatives, 3(2), 324-340.

De Wet, C. (2006) Introducing the issues. In: Development-induced Displacement: Problems, Policies and People (ed C. De Wet) pp. 1-12. Bergahn Books, New York.

Downing, T.E. \& Garcia-Downing, C. 2009 Routine and dissonant cultures: A theory about the psycho-socio-cultural disruptions of involuntary displacement and ways to mitigate them without inflicting even more damage. In: Development and Dispossession: The Anthropology of Displacement and Resettlement (ed A. Oliver-Smith) pp. 225-254. School for Advanced Research Press, Santa Fe, NM.

Electricity of Vietnam (EVN) (2004). Bao cao danh gia tac dong moi truong 
(Environmental impact assessment report for the A Vuong dam, Quang Nam province). Hanoi.

Fearnside, H.M. (2001) Environmental impacts of Brazil's Tucurui dam: Unlearned lessons for hydroelectric development in Amazonia. Envir. Mgmt., 27(3), 377-396.

Government of Vietnam (2010). Decree No. 992010/ND-CP. On the policy for payment for forest environmental services. Socialist Republic of Vietnam, Hanoi.

Haas, L. (2009) Improving benefit sharing around large dams. In: Sharing the Benefits of Large Dams in West Africa. Natural Resource Issues No. 19 (eds J. Skinner, M. Niasse, \& L. Haas) pp. 23-46. International Institute for Environment and Development, London, UK.

Hirsch, P. (2006) Water governance reform and catchment management in the Mekong region. The J. of Envir. and Dev., 15(2), 184-201.

Hung, L. (2007) A contribution to Katu ethnography. The Gioi Publishers, Hanoi.

International Commission on Large Dams (ICOLD) (2013). Number of dams by country members. Available from URL: http://www.icold-cigb.org/GB/World_register/ general_synthesis.asp?IDA=206. Accessed 12 July 2013.

International Water Management Institute. (2011). Policy review and institutional analysis of the hydropower sector in Lao PDR, Cambodia, and Vietnam. Final report.

Johnson, B.R. (2012). Water, culture, power: Hydrodevelopment dynamics. In: Water, cultural diversity, and global environmental change: Emerging trends, sustainable futures? (ed B.R. Johnston, L. Hiwasaki, I.J. Klaver, A. Ramos Castillo, V. Strang), pp. 295-318. Springer, Dordrecht, Netherlands.

Kerkvliet, B.J.T. (2003) Authorities and the people: An analysis of state-society relations in Vietnam. In: Postwar Vietnam: Dynamics of a transforming society (ed H.V. Luong) pp. 27-54. Rowman and Littlefield Publishers, Oxford.

Koenig, D. (2006) Enhancing local development in development-induced displacement and resettlement projects. In: Development-induced Displacement: Problems, Policies and People (ed C. de Wet), pp. 105-140. Bergahn Books, New York.

Kolinnjivadi, V. \& Sunderland, T. (2012) A review of two payment schemes for watershed services from China and Vietnam: The interface of government control and PES theory. Ecol. and Soc. 17(4): 10.

Kuenzer, C., Campbell, I. Roch M., Leinenkugel P., Vo Q.T. \& Dech, S. (2012) Understanding the impact of hydropower developments in the context of upstream-downstream relations in the Mekong river basin. Sustain. Sci., 8(4), 565-584.

Lux, S.J. \& Straussman, J.D. (2004) Searching for balance: Vietnamese NGOs operating in a state-led civil society. Public Admin. and Dev., 24, 173-181.

McElwee, P. (2009) Reforesting "bare hills” in Vietnam: Social and environmental 
consequences of the 5 million hectare reforestation program. AMBIO: A J. of the Hum. Environ., 38(6), 325-333.

Mgbako, C., Gao, R.E., Joynes, E., Cave, A. \& Mikhailevich, J. (2010) Forced eviction and resettlement in Cambodia: Case studies from Phnom Penh. Washington U. Glob. Studies Law Rev., 39(1), 40-62.

Ministry of Environment and Natural Resources (MONRE), Government of Vietnam (2008) SEA of the Quang Nam Province Hydropower Plan for the Vu Gia-Thu Bon river basin: Final Report.

Ministry of Trade and Industry (MOIT), Government of Vietnam (2009) Strategic Environmental Assessment of the Hydropower Master Plan in the Context of the Power Development Plan VI: Final Report.

Mokorosi, P. S., \& van der Zaag, P. (2007). Can local people also gain from benefit sharing in water resources development? Experiences from dam development in the Orange-Senqu river basin. Physics and Chem. of the Earth, Parts $A / B / C$, 32(15), 1322-1329.

Munro, J.L., Iskander and Costa-Pierce, B.A. (1990) Fisheries of the Sagulung reservoir and a preliminary appraisal of management options. In: Reservoir Fisheries and Aquaculture Development for Resettlement in Indonesia (eds B.A. Costa-Pierce \& O. Soemarwoto) pp. 285-328. Perusahaan Unum Listrik Negara, Jakarta.

Nakayama, M. \& Furuyashiki, K. (2009) Renting Submerged Land for Sustainable Livelihood Rehabilitation of Resettled Families: Cases of Jintsu-gawa Dams in Japan. Int. J. of Water Res. Dev., 25(3), 431-439

Nayak, R. (2000) Risks associated with landlessness: an exploration toward socially friendly displacement and resettlement. In: Risks and Reconstruction: Experiences of Resettlers and Refugees (eds M.M. Cernea and C. McDowell) pp. 79-107. The World Bank, Washington, D.C.

OECD Development Assistance Committee (1992) Guidelines on aid and environment no. 3: Guidelines for aid agencies on involuntary displacement and resettlement in development projects. Available from URL: http://www.oecd.org/environment/environment-development/1887708.pdf. Accessed 12 October 2013.

Nguyen, P.M. (2013, August 31) Vietnam worried about dam safety in rainy season. Southeast Asia Realtime. The Wall Street J.

Pandya, H. (2013) Involuntary displacement: An analysis of the role and contribution of non-governmental organizations to the Narmada Project affected communities in Western India. Intl. NGO J., 8(2), 44-53.

Pham, T.T., Hoang, M.H. \& Neves, N. (2008) Pro-poor payments for environmental 
services: Challenges for the government and administrative agencies in Vietnam. Public Admin. and Dev., 28, 363-373.

Quang Nam Province Department of Agiculture and Rural Development (2013) Unpublished statistical data on forest cover.

Rahaman, M. M., \& Varis, O. (2005) Integrated water resources management: evolution, prospects and future challenges. Sustainability: Science, Practice \& Policy, 1(1), 15-21.

Scott, S., Miller, F. \& Lloyd, K. (2006) Doing fieldwork in development geography: Research culture and research spaces in Vietnam. Geog. Res., 44(1), 28-40.

Scudder, T. (2005) The Future of Large Dams: Dealing with Social, Environmental, Institutional and Political Costs. Earthscan, Oxford.

Singer, J. \& Hai, H. (2013-14) Participation in resettlement decision-making by dam-displaced villagers in central Vietnam. Asia J. of Global Studies, 6(1), 15-28.

Tan, Y. \& Yao F. (2005) Three Gorges project: Effects of resettlement on the environment in the reservoir area and countermeasures. Pop. and Environ., 27(4), 351-371.

Thanh, L.D. (2013). Water resources and issues concerning sustainable watershed management practices in Vietnam. In: Water Issues in Southeast Asia: Present Trends and Future Directions (ed L.P Onn) pp 286-315. Institute of Southeast Asian Studies, Singapore.

Thayer, C.A. (2009) Vietnam and the challenge of political civil society. Contemp. SE Asia 32(1), 1-27.

Ty, P. H., Van Westen, A.C.M., \& Zoomers, A. (2013). Compensation and resettlement policies after compulsory land acquisition for hydropower development in Vietnam: Policy and practice. Land, 2(4), 678-704.

Viet Nam News (2013, Sept. 3) Tremor hits Bac Tra My District. Available from URL: http://vietnamnews.vn/society/244356/tremor-hits-bac-tra-my-district.html. Accessed 25 October 2013.

World Bank (2013) OP/BP 4.12 Involuntary Resettlement. Available from URL: http://web.worldbank.org/WBSITE/EXTERNAL/PROJECTS/EXTPOLICIES/EXTOP MANUAL/0,,contentMDK:20064610 menuPK:4564185 pagePK:64709096 piPK:647 09108 theSitePK:502184,00.html. Accessed 3 September 2013.

World Commission on Dams (2000) Dams and Development: A New Framework for Decision-making. Earthscan, London.

Wunder, S. (2005) Payments for Environmental Services: Some Nuts and Bolts. CIFOR Occasional Paper No. 42, 24.

Wunder, S. (2008) Payments for environmental services and the poor: concepts and preliminary evidence. Envir. and Dev. Econ., 13, 279-297. 
Table 1.

Designated forest land near the A Vuong hydropower dam

\begin{tabular}{|r|r|r|r|r|r|r|}
\hline Year & Area (ha) & $\begin{array}{c}\text { Natural } \\
\text { forest }\end{array}$ & $\begin{array}{c}\text { Plantation } \\
\text { forest }\end{array}$ & $\begin{array}{c}\text { Vacant } \\
\text { (degraded) } \\
\text { land }\end{array}$ & $\begin{array}{c}\text { Other land } \\
\text { (incl. } \\
\text { cultivated } \\
\text { inlandarea) }\end{array}$ & $\begin{array}{c}\text { Forest } \\
\text { coverage } \\
\text { (\%) }\end{array}$ \\
\hline 2003 & 81,129 & 49,231 & 3,200 & 23,868 & 4,830 & 65 \\
\hline 2004 & 81,129 & 49,231 & 3,200 & 23,868 & 4,830 & 65 \\
\hline 2005 & 81,129 & 49,228 & 3,200 & 23,871 & 4,830 & 65 \\
\hline 2006 & 81,129 & 49,214 & 3,228 & 23,673 & 5,014 & 65 \\
\hline 2007 & 81,129 & 49,220 & 3,249 & 23,604 & 5,055 & 65 \\
\hline 2008 & 81,129 & 48,387 & 3,635 & 14,145 & 14,963 & 64 \\
\hline 2009 & 81,129 & 48,387 & 3,870 & 13,978 & 14,894 & 64 \\
\hline 2010 & 81,263 & 40,875 & 4,496 & 20,912 & 14,980 & 56 \\
\hline 2011 & 81,263 & 40,875 & 4,544 & 20,895 & 14,950 & 53 \\
\hline 2012 & 81,263 & 40,875 & 5,297 & 20,278 & 14,814 & 56 \\
\hline 2013 & 81,263 & 43,472 & 6,436 & 19,608 & 11,748 & 57 \\
\hline
\end{tabular}

Source: Department of Natural Resources, Quang Nam Province, 2014 
Figure 1. River basin impacts of dam-induced resettlement

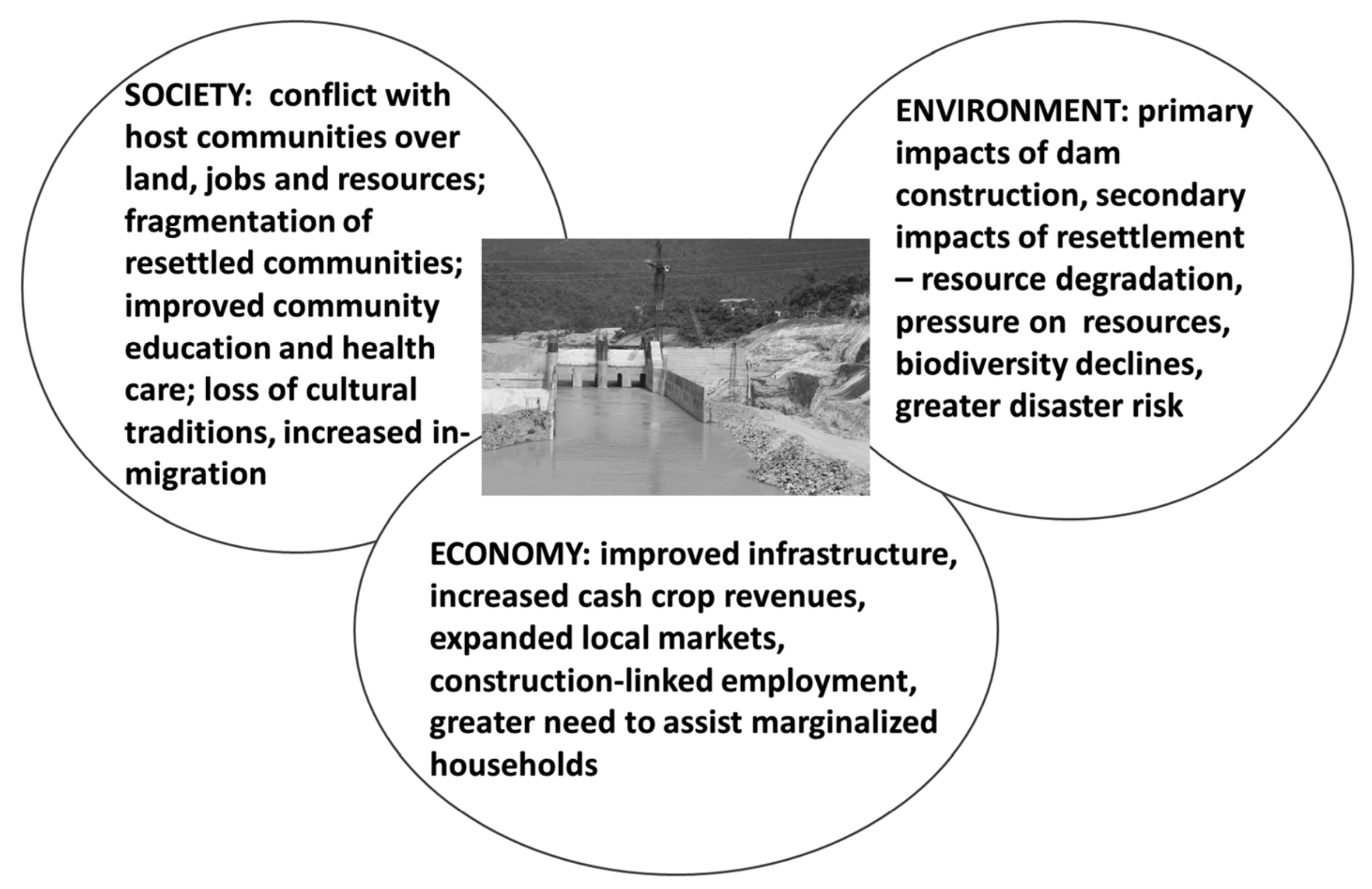


Figure 2. Field site

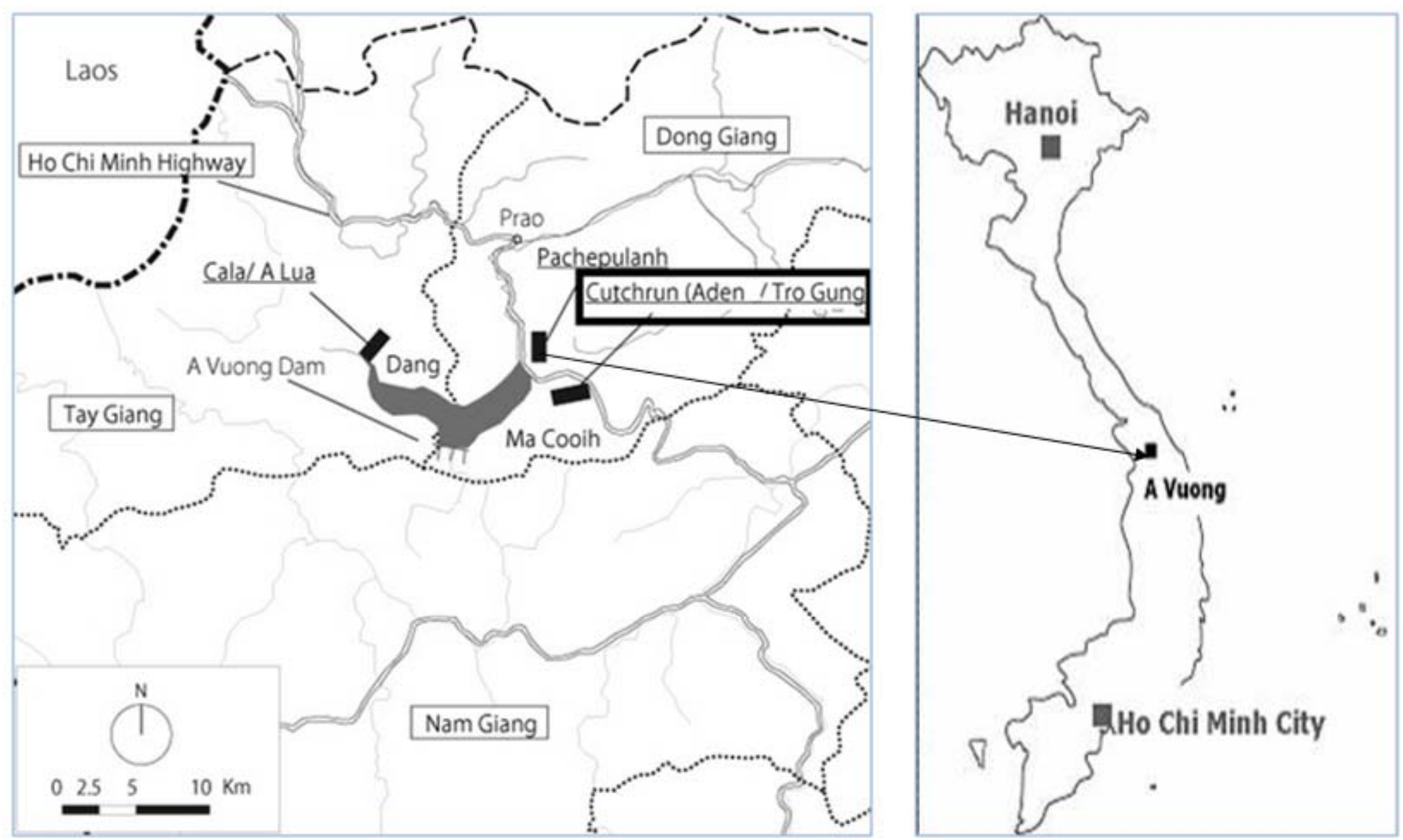

